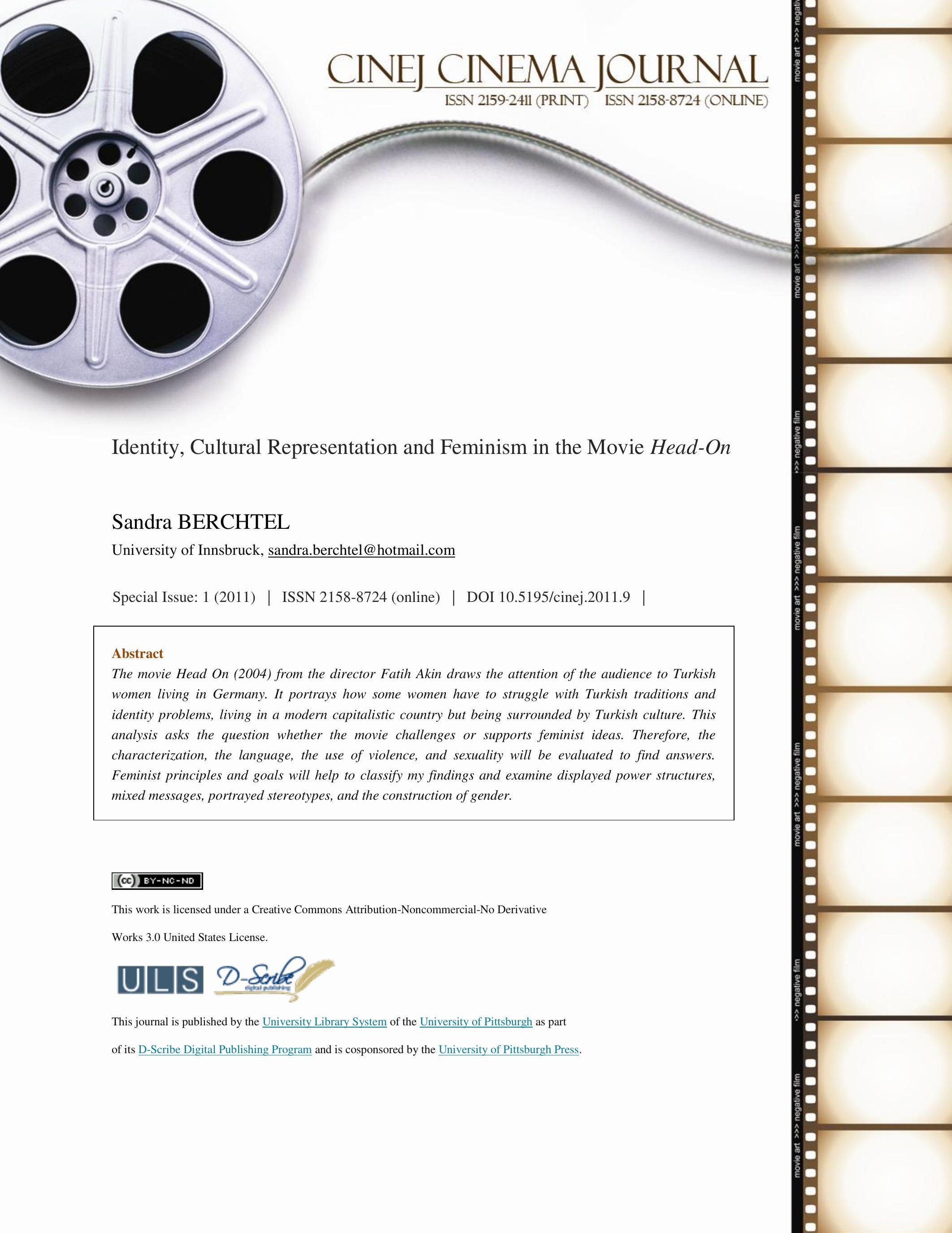




\section{Identity, Cultural Representation and Feminism in the Movie Head-On}

\section{Introduction}

“Are you Turkish? Do you want to marry me?"1 These questions asked by Sibel (Sibel Kekilli), the main character of the movie Head-on (2004), are the beginning of a conversation between her and Cahit Tomruk (Birol Ünel). It seems completely absurd and hard to understand without any background information and cultural knowledge, why a young and pretty girl would ask the first "bum" ${ }^{2}$ crossing her way to marry her. Nevertheless, it captures our attention, it provokes and forces us to have a closer look at the situation. That happened to most of the viewers, when they saw the movie for the first time in the cinema. It was fascinating and powerful as well as hard and brutal. The controversial topics were discussed among Turkish immigrants, Austrians and Germans and within the media. Liberal politics used the film to argue for better immigration policies and conservative politics abused it to underline cultural stereotypes. ${ }^{3}$

\section{Artefact}

Head-on portrays the life of Sibel, a young woman with Turkish roots, growing up in Germany. To escape from her oppressive father and brother, she marries Cahit. Cahit is bad tempered, aggressive, and addicted to alcohol and drugs. He does not care about anybody, not even about himself. Sibel's father accepts him as a sonin-law because he is Turkish. Sibel hopes that through this marriage she will be able to experience life, which means in her definition to have parties, sex, and drugs, without having anybody who rules over her. Time passes, the couple gets to know each other better, and despite all the aggression and fights, they fall in love. However, one of Sibel's lovers provokes Cahit until he kills him in anger. Cahit is arrested and Sibel has to flee to Istanbul because her brother wants to kill her to save the honor of the family. In Istanbul Sibel's suffering continues. She is full of doubt and guilt and very depressed without Cahit. Her life becomes more and more extreme until she reaches a point, where she has the same self-destructive behavior Cahit had in the beginning of the movie. Again, she is the victim and is raped by the owner of a bar, who promised to employ and accommodate her. Then, that same night, three guys beat her up and nearly kill her with a knife. Finally, a cab driver finds and helps her. A couple of years later Cahit is released and searches for Sibel. In the meantime she gets a boyfriend and has a daughter. However, Cahit and Sibel meet in a hotel in Istanbul, where they also have sex for the first time. Cahit offers Sibel a new life together and waits for her at a bus station. Despite her promise to come, she finally decides to stay with her family. ${ }^{4}$

\section{Method}

Feminist Criticism is part of the cultural approaches and therefore analyzes rules, values, and habits existing within a culture. It does not - like other approaches - focus on the rhetor or the audience, but rather focuses on ideologies. The primary goal, therefore, is to discover and visualize whose interests are represented in the ideology of the artifact. ${ }^{5}$ It is a deductive method, hence, it starts with a set of assumptions and verifies if they are present. Important hereby are language, body language, images, imagery, metaphors, actions, roles, techniques etc. Nevertheless, it also examines what is neglected or deflected, because the denied or missing parts also provide information. ${ }^{6}$ 
Feminist Criticism developed from the political and social movement in the 1970s. The question, how to define feminism, is still an ongoing process, which is also influenced by unique needs and experiences of different women. Bell Hooks points out that for a black lower class woman the phrase to be equal has other implications than for a white upper class woman, who simply will experience oppression, defined as a lack of choices, differently. ${ }^{7}$ This is also important to consider for the movie Head-on, because it deals with lower to middle class Turkish immigrants living in Germany and concentrates on issues like class, race, religion, and culture.

Nevertheless, the feminist movement is based on three basic principles: "1. Women are oppressed by patriarchy", "2. Women's experiences are different from men's" and "3. Women's perspectives are not now incorporated into our culture". ${ }^{8}$ Furthermore, there are two common goals: "to end sexist oppression" and "to change existing power relations between women and men". ${ }^{9}$ These principles and goals will help to classify and analyze my findings, provide the structure to study the construction of gender and help to evaluate how patriarchy is portrayed.

\title{
IV. Characterization
}

This movie portrays four important female characters: Maren (Catrin Striebeck), Selma (Meltem Cumbul), Birsen Güner (Aysel Iscan), and the heroine Sibel (Sibel Kekilli). ${ }^{10}$

Maren has a sexual relationship with Cahit. She is used to not expecting anything from him and just handles all his bad temper and aggression. Sometimes she asks him very carefully which mood he is in, to make sure not to provoke him. Her behavior is most of the time servile, but she also can react very aggressively. Even their sexuality is sadomasochistic, and portrays their struggle over power. The language they use is shocking, very emotional, and lacks any respect.

\author{
Maren: How was the concert? \\ Cahit: Piss off, Maren! \\ Maren: Asshole! \\ Cahit: Fuck you! \\ Maren: Motherfucker! ${ }^{11}$
}

Furthermore, she helps Cahit by hiring Sibel as hairdresser. She is the only German woman in this movie. This shows on the one hand, that Cahit denies everything Turkish and is better integrated into the German culture than the other portrayed men. But it demonstrates on the other hand, that not only Turkish women are treated badly by men. All in all, her character is portrayed as a willing woman who loves her oppressor and the sexual intercourse with him so much that she tolerates his bad treatment towards her.

Selma, Sibel's cousin, lives in Istanbul and is an independent and successful woman. She is divorced and seems very open-minded. She is patient, friendly, and helps Sibel after her arrival in Istanbul. The relationship between Selma and Sibel changes a lot: In the beginning Selma is an idol for Sibel. Sibel admires that Selma is single and trusts her more than anybody else. But later Sibel despises her because she is a career woman who works too much. Sibel even blames her desire to make a career as reason for the failed marriage. Being without a 
man suddenly seems to be something to judge. Selma also answers Cahit's question about her well-being, with: "As you see ... I'm still single ..." Selma is the only woman who is not in a relationship. However, she is the only one who does not need help and who has her life in control. Nevertheless, through Sibel's perspective and Selma's own references to being single, it also seems as if she is lacking something. This provides a very ambiguous message for women.

Birsen Güner is Sibel's mother. Her appearance does not fulfill conservative Turkish stereotypes, because she does not wear a head scarf (neither does any other woman), and she has bleached, short hair. Nevertheless, all her behavior demonstrates a stereotypical subordinate woman, who is completely oppressed by the male part of her family. The only time she overcomes her weakness and tries to fight against her husband is when he burns the picture of his daughter to deny her existence. Apart from that, the only way she knows to help Sibel is to teach her how to survive by accepting the oppression. Ironically, the mother is the reason why Sibel doesn't run away from the family in the beginning and chose the accepted way to escape. The relationship between her parents is onesided. The mother tries everything to unite her family and her husband blames her for being too supportive and hence, too liberal: "She's [Sibel] made mistakes because of how you raised her."13
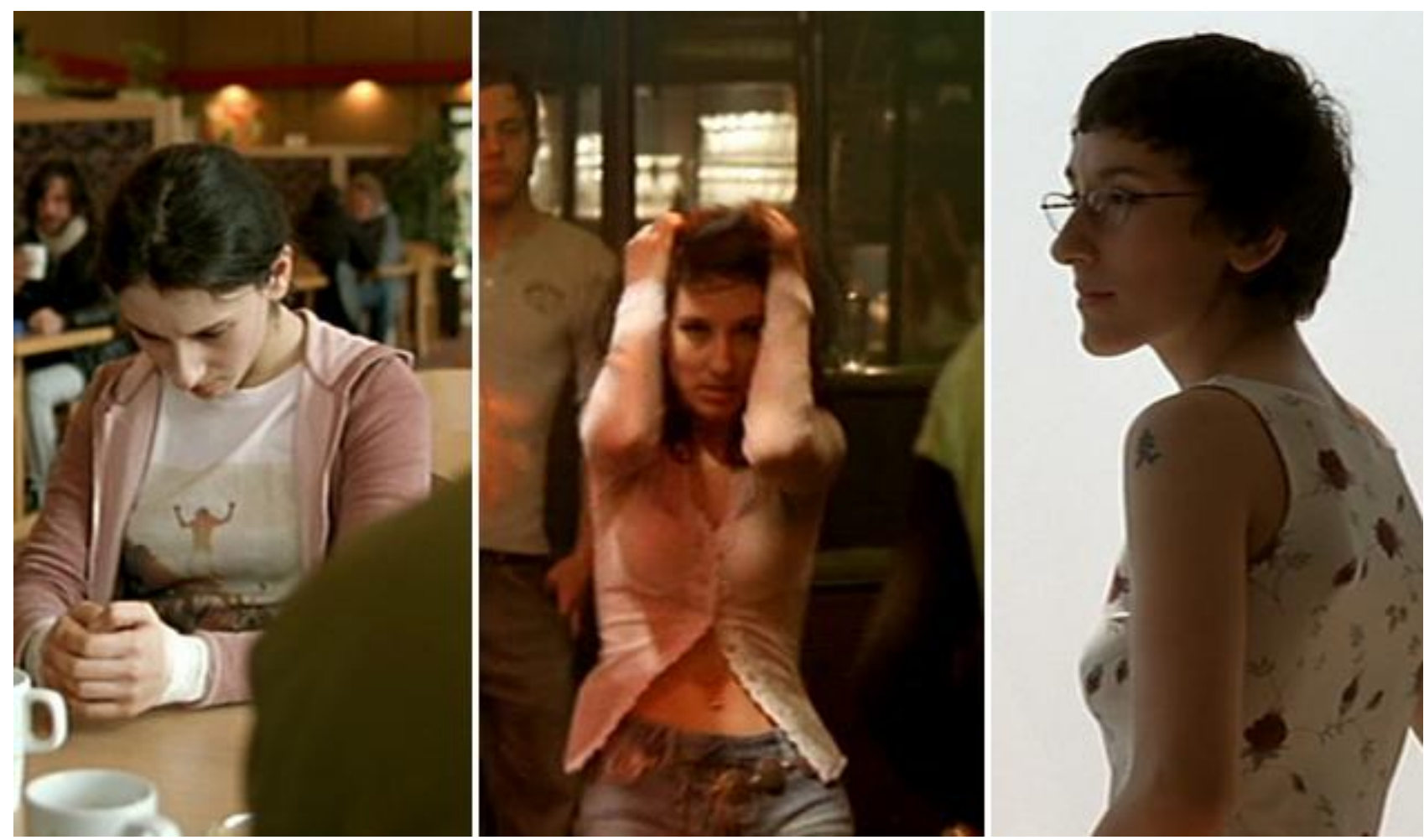

Sibel, the main character, is a round and developing character. This is portrayed through her look and her statements. After her marriage, she starts to dress very sexy, wears a piercing and uses a lot of make up. At the end of the movie she looks very serious, has a short haircut and wears glasses. Her values change the same way, from very liberal to rather conservative, which is demonstrated by judging Selma's lifestyle but also at the end of the movie by deciding to stay with her new family.

Sibel struggles for freedom without caring about anybody except herself and maybe in the beginning about her mother. For example, she reacts very insensitively when Cahit talks about having children together. She just 
answers, that if her mother keeps asking, she will tell her that he is impotent. She categorically denies being a wife and/ or mother in the first half of the movie. Everything she wants is to be free, to party, to consume drugs, to dance, and to sleep with men. Niko, who finally gets killed by Cahit, has a one-night-stand with Sibel. At that time, he does not know that she is married and he tries to talk to her, but she shoves him away very unfriendly. She even tells him, that she just slept with him to find out how his sexual qualities are.

Niko: What? you $!^{15}$

Sibel: Leave me alone. I'm a married Turkish woman. Try anything and my husband will kill

Suddenly she also uses the fact that she is Turkish and married whenever she needs protection from men. Unfortunately, in Niko's case, her accusation comes true. After this incident, it is clear for every male - her father, her brother and even Cahit's Turkish friend, Seref (Güven Kiraç) - that Sibel is guilty and responsible for Cahit's violent actions, because her sexual behavior causes them.

Sibel: They'll kill me.

Seref: Who?

Sibel: My family.

Seref: Your family! What do you expect? You fuck everything up and then cry, "My family!" $[\ldots]$

Seref: Can't you see what you've done to him? You've ruined his life! ${ }^{16}$

\section{Language}

The use of language can reveal the attitude of the speaker. ${ }^{17}$ Therefore it is interesting to see how men in this movie address women. Some of the degrading words are "babe" and "girl" (used to indicate that Sibel is naïve); even more offending are "my old lady" and "lying bitch". The movie also contains a selection of sexual insulting descriptions, for example "nice cute chick" and "lying cunt"18.

The language used in dialogues has the same characteristics, it is insulting and degrading (for example: "fuck off, fuck you, piss off, I'll fucking show her"19 etc.). Even when Sibel tries to be a serving wife, Cahit mocks her:

Cahit: It's like a chick-bomb exploded in here! [after Sibel cleaned and decorated his apartment] Cahit: Marrying you wasn’t such a bad idea. [after she spent hours cooking for him] ${ }^{20}$ 
Furthermore, the movie contains descriptions about how women are in general. For example, when Cahit tries to explain the wedding plans to his Turkish friend Seref:

Cahit: She says she'll kill herself if I don't do it.

Seref: The fuck she will. And you believe her? Women are like that. They make up stories to trap you. You know what getting married means?

Cahit: No, I don't.

Seref: Problems! $[\ldots]^{21}$

The language in the whole movie is negative, brutal, and vulgar - especially when it is about, towards or in connection with women. Similar to the extreme characterization, the audience might distance themselves from the used language. However, it also intensifies the rejection of the patriarchic power structure.

\section{Violence}

The first threat against woman can be watched in the very beginning of the movie, in the waiting room of the psychiatric clinic. Two German patients are talking two each other silently. This demonstrates that violence against women is not something foreign, which can only occur in Turkish culture.

Patient: My old lady brought me here. She said to Dr. Schiller, I am afraid of my man. What does that make me? Lying Bitch! But I got people, I'm telling you. I'll fucking show her. [...] I'll show her, I tell you. She won't get away with it. ${ }^{22}$

Sibel gets kicked out from a bus, an apartment, Germany, and a bar by men. This symbolizes that she has no rights and men can decide over her. The first time, a Turkish male bus driver accuses Sibel and Cahit as "godless dogs" and he throws them out of the bus. The second time, Cahit kicks Sibel out of his apartment on their wedding night, for asking him about the name of his previous wife. By throwing a beer can after her, it is also the first time violence is included.

S: Can I ask you something?

C: Sure.

S: What was your wife's name? [He throws a beer can after her.]

S: What the hell?

C: Out! Piss off, God damn it! [He kicks her out]

(On the next morning she is waiting on the stairs until he lets her in) ${ }^{23}$ 
When it comes to Sibel's brother, Yilmaz, violence becomes real. He has already broken her nose because he saw her holding hands. After she tries to attempt suicide, instead of helping her, he threatens her.

Yilmaz: Can't you see what you are doing to him [father]? It's killing him. Look at me! Look at me! If anything happens to the old man, you're dead meat. ${ }^{24}$

After Cahit gets arrested, her brother tries again to "save the honor" of the family. He literally hunts her, but she is faster and is finally able to leave the country before he can catch her.

The worst attack against Sibel happens in Istanbul. Sibel gets brutally raped by the owner of a bar, while she is nearly unconscious because of drug and alcohol abuse. Afterwards, he wakes her up without even putting her pants back on. It seems there is no need for him to be afraid that Sibel could realize what happened and hence report him. After she left the place three young guys assault her on the street. She is so desperate that she reacts with violence and aggression. It gives the impression she wants them to kill her. After they beat her up and even use a knife, they run away and leave her lying on the street, unaware if she will survive or not. She is found by a cap driver, who helps her.

\section{Sexuality}

Sexuality is omnipresent in this movie. It is full of talking about sexuality as well as showing naked bodies or body parts and showing couples having sex. In feminist critiques the exposition of women's bodies to the male gaze is an important issue. In this movie Sibel is shown naked and her body is filmed in a pornographic way, for example emphasizing close-ups from her cleavage and her hips. Sequences where she is dressing or undressing are shown frequently and there is also a scene showing her from a high-angle shot taking a shower. Most of the time when it comes to this sexual exposition, the camera portrays Cahit's or another male's perspective watching the women. Cahit is also filmed in that way and there are several shots showing him naked and fragmented. Laura Mulvey split scopophilia in her legendary essay "Visual Pleasure and Narrative Cinema" into active/ male and passive/female ${ }^{25}$. In this movie women are still more passive than men, but the usual order is challenged by also filming men as exposed objects.

The sexuality portrayed in the movie usually is about power and violence, for example the already mentioned sadomasochistic intercourse between Maren and Cahit, or the raping of Sibel. A more romantic and loving way of sexuality is portrayed between Cahit and Sibel. However, the first time they were going to have sex, she interrupts his attempts and they have no sexual relationship until he finds her in Istanbul after his imprisonment.

Sibel: Stop! Stop! Stop it! I can't! I can't! If we do it, then I'm your wife and you're my husband. Understand? ${ }^{26}$

Again, sexuality is connected to power-structure. Sibel is afraid that sleeping with Cahit would bind her to him; she prefers to be a whore over being his wife. Therefore, sexuality is also about women being the 
possession of their husbands. This is shown clearly in the way men speak among each other about women. The following example is from the sequence when Niko provokes Cahit before he gets killed:

Niko: You're her pimp right? [...] Does her cunt bring in good money? Tell me... What does it cost if I want to fuck her in the ass? Is 50 Euros enough? I want to fuck your Turk the Greek way! ${ }^{27}$

\section{Three Principles of Feminist Criticism}

1. Women are oppressed by patriarchy

The male perspective in this movie portrays women either as wives or as whores. Wives (e.g. Sibel's mother) have to do all the housework, are quiet and behaving servants, and never complain about anything. They don't have many rights or the same privileges as their husbands. For example, it seems to be normal for Turkish husbands to visit a brothel.

The whores (e.g. Maren) are willing women who can be degraded through language and action. Their reason to exist is to please men. Men have absolute power over them. By marrying Cahit, Sibel has chosen to become a whore to avoid becoming a housewife.

Sibel: I'm too young to marry seriously. Should I become a housewife? ${ }^{28}$

[Explanation to Selma why she has chosen Cahit]

However, she does not realize that being a whore does not provide the freedom she was seeking. At the end of the movie she finally decides to become a wife. Hence, she stays in these two categories. The only exception is Selma, who does not fit in either category because she has no man on her side. Thus, she does not seem to be oppressed. However, it still seems to be a loss to be single.

The reality of this oppression is often portrayed in little details. For example, in a conversation with the whole family, Sibel and her mother sit with folded hands looking humbly to the ground. After the male part of the family leaves, they relax, sit back, smoke, and Sibel lets her hair down.

2. Women's experiences are different from men's

Sibel's behavior is always extreme. Nevertheless, there are many parallels between her and Cahit's behavior. Before Cahit attempts suicide by driving a car straight into a wall in the beginning of the movie, the background music is a popular song from Depeche Mode. A part of the same song is played when Sibel dances completely out of control in the night in Istanbul, before she gets raped and nearly killed. The major difference is that Cahit (the man) nearly destroys himself, whereas Sibel (the woman) is the victim and nearly gets destroyed by men. Therefore, a major theme in this movie is that men and women often experience different treatment. 
Sibel's family is another example for this. Her father and her brother have through their gender different rights than Sibel or her mother. Hence, for her brother it is easy to accept the traditional Turkish culture, which provides him a lot of advantages over women.

3. Women's perspectives are not now incorporated into our culture

Sibel undoubtedly challenges the patriarchic power structure throughout the whole movie. She does everything to fight for her independence and her freedom. Through her struggle, Akin Fatih tries to change the third of the three feminist principles, because the movie shows us her fight and therefore the perspective of women. It also portrays how hard it is for Sibel, and therefore for women in general, to free themselves. Sibel does not let anybody silence her and finally successes in living her life and makes her own decisions. Since she is the main character, and a major part of the movie is filmed through her perspective the audience most probable will identify with her. However, her ambiguity might challenge sometimes the sympathy towards her, but she is still the most likeable.

\section{Supporting vs. Challenging Feminist Ideas}

1. Males challenging patriarchic power structure

Cahit is a very ambiguous character. He contradicts with Sibel, with being Turkish, and with the illusion of a good husband; he basically does not fit into any culture or description. Besides, he has as many good characteristics as bad. He marries Sibel to rescue her, but treats her awfully. His anger and violence is uncontrollable against both genders and also himself. He does not accept traditions and rules. Therefore he is the only male who challenges the patriarchic power structure by confronting other Turkish males:

Man 1: I was in "Pascha" last week. There were lots of new chicks there. Scandinavian, African...

Man 2: Any Turkish ones?

Man 1: I got enough of them at home.[...]

Man 2 to Cahit: Hey brother-in-law, you should come with us some time.

Cahit: Where to?

Man 2: The brothel.

Cahit: What would I want there?

$[\ldots]$

Cahit: Why don't you fuck your own wives? $[\ldots]^{29}$

Cahit is disgusted about the way other men talk about women and so he challenges their double standards. In another scene, after Cahit is released from prison he also asks Yilmaz, Sibel's brother, where he 
could find Sibel. Again Cahit challenges Yilmaz's worldview by questioning his behavior. He also points out, that their mother must suffer tremendously because of Yilmaz's attempts to save their honor.

Yilmaz: I have no sister now. [...] We had to save our honor. Don't you see?

Cahit: Did you save it, your honor? $?^{30}$

These two examples demonstrate how the patriarchic power structure is challenged by Cahit. However, Cahit sends mixed messages about feminist ideas by treating women badly, but challenging male perspectives.

\section{Mixed Messages}

Besides Cahit, the women also send mixed messages. Maren is a very strong and powerful woman, but she loves her oppressor Cahit, who permanently degrades her. Sibel's mother is loving and nice, but weak and hence, accepts her role as serving wife and mother. Selma is independent and the only woman who is not oppressed by patriarchic power structure; nevertheless she seems to lack a partner. Sibel, the most important character, is at the same time the most controversial. She radically fights for freedom without caring about herself or anybody else. However, she is not able to control herself and handle her new freedom after the oppression. Cahit tells his friend Seref that Sibel rescued him and only because of her he could survive the prison. However, Sibel also needs a man to help her twice. First, she persuades Cahit to marry her and second, the cab driver in Istanbul finds her and helps her after three guys had beaten her up. Therefore, she can't survive without the help of men. In Istanbul, she is also completely helpless and depressed, it seems she does not function without Cahit anymore, or she feels guilty about him being in prison. Either way, it affirms the patriarchic power structure.

Sibel's relationship with Selma also sends mixed messages. Sibel's admiration for her liberal and independent cousin changes into spite about her ambition to make a career. At the end of the movie Sibel decides to stay with her daughter and boyfriend instead of leaving with Cahit, the man she loves. Therefore, she is accepting the role to be a mother and a wife. It seems she is sacrificing her passion for her new family, following her biological determination which she fought so long.

\section{Conclusion}

The main character Sibel is a strong woman, who finally manages through great will and strength to free herself and live a better life. The movie shows the perspective of a woman and demonstrates the oppression and disadvantages women have to face. Through the degrading use of language, sexuality and violence, Fatih Akin, the director of the movie, challenges the dominant and oppressing patriarchic power structure, because the viewers will judge the extreme behavior towards women negatively. Moreover, the characterization of women and men portrays how gender roles are constructed and how different treatment will be experienced.

Hence, the movie supports the first goal of feminism "struggle to end sexist oppression" 31 , because Sibel's portrait can awaken women to fight for their rights and also allows a critical view of unsolved and ignored problems in modern societies. The second goal "to change existing power relations between women and men" ${ }^{\prime 3}$, is only partly affirmed. Depending on the interpretation of the audience and the judgment about Sibel's character, the movie could also reaffirm stereotypes and the existing power structure. Furthermore, this analysis also revealed 
some mixed messages, which rather support the patriarchal hegemony. It could be argued that this was necessary to satisfy the viewers, fulfill some expectations, etc. Or, it shows that even the most commendable attempt still implies patriarchic power structure, which might seem so natural that nobody questions it.

However, it is an inconvenient movie, which simply does not fit into one category. This might be disappointing for viewers who expected clear messages, but in my opinion it is the strength of the movie, because it seems to be realistic which makes it very powerful. Therefore, I argue that the movie in general supports feminist ideas by demonstrating and judging the oppressing patriarchic power structure, and by incorporating women's perspectives and illustrating their struggle to survive.

The movie was successful which can be confirmed by the number of people who went to the cinema and the enormous echo in the press. Akin could draw the attention of a lot of people to his message. But it is not possible to measure if it changed anything in the reality of Turkish women living in Germany within this paper and by using this method.

It also would be wrong to generalize that all Turkish women living in Germany are suffering under the oppression of their culture. It is also hard to judge a foreign culture without having enough insight to understand it. However, the problem exists, and Fatih Akin is not the first and won't be the last one to draw the attention toward it. The enormous response to his movie demonstrates its importance and actuality. Even if he could not change the world with one movie, he at least tries to sensitize the audience to this topic and affirms that a problem exists. 
1 HEAD-ON (2004).

2 Ebd.

${ }^{3}$ Compare to http://www.bpb.de/files/CDVFQZ.pdf.

${ }^{4}$ Compare to: Head-on (2004).

${ }^{5}$ Compare to: Foss, p. 213.

${ }^{6}$ Compare to: Weimer, Cultural Approaches, p. 1-2.

${ }^{7}$ Compare to: hooks, p. 5 and 18-19.

${ }^{8}$ Weimer, Feminist Criticism, p.1.

9 Ebd.

${ }^{10}$ Compare to: http://www.imdb.com/title/tt0347048/

11 Head-on (2004).

12 Ebd.

13 Head-on (2004)

14 Ebd.

15 Head-on (2004)

16 Ebd.

${ }^{17}$ Compare to: Weimer: Cluster-Agon approach

18 Head on (2004)

19 Ebd.

20 Ebd.

21 Ebd.

22 Head on (2004).

23 Ebd.

24 Ebd.

${ }^{25}$ Compare to: Mulvey, p. 19-20.

26 Head-on (2004).

27 Head-on (2004).

28 Ebd.

29 Head-on (2004).

30 Ebd. 


\footnotetext{
${ }^{31}$ Weimer, Feminist Criticism, p.1.

32 Weimer, Feminist Criticism, p.1.
}

\section{References}

Filmzeit (German movie data base) by Kombinat Berlin: Collection of responses in different newspapers to the movie: <http://www.film-zeit.de/Film/12060/GEGEN-DIE-WAND/Presse/> (02/10/2010).

Foss, K. S. (2009). Rhetorical Criticism. $4^{\text {th }}$ ed. Illinois: Long Grove.

Head-on (2004). Directed and written by Fatih Akin and produced by Fatih Akin, Andreas Schreitmüller and Stefan Schubert, 121 min. DVD.

Hooks, B. (1999). Feminist Theory. From Margin to Center. $2^{\text {nd }}$ ed. Cambridge, MA: South End Press.

IMBD (The Internet Movie Database): Cast. http://www.imdb.com/title/tt0347048/ (04/17/2010)

Interview with Fatih Akin: CINEMA. Hamburg: Cinema Verlag GmBH <http://www.cinema.de/stars/star/fatihakin,1574206,ApplicationStar.html?tab=\&article=3122026> (02/10/2010).

Interview with Fatih Akin: FILMNEWS <http://www.filmnews.at/interviewakin.php> (02/10/2010).

Mulvey, L. (1989). Visual Pleasure and Narrative Cinema. Bloomington: Indiana UP.

Weimer, D. (2010). Cluster-Agon Approach, Cultural Approaches, Feminist Criticism, The Neo-Aristotelian/ Traditional Approach. CM 330 class handouts. Juniata College.

Wienen, A., \& Twele, H. (2004). Filmheft (Movie brochure) "Gegen die Wand", Bonn: Bundeszentrale fuer politische Bildung/ bpb. 2004. <http://www.bpb.de/files/CDVFQZ.pdf> (02/13/2010)

Sandra Berchtel studied German language, Philosophy and Psychology at the University of Innsbruck in Austria and at the University of Jyväskylä in Finland. Besides, she was teaching German language courses to immigrants in an Institute for apprenticeship and advanced training. Afterwards, she completed her one-year teaching internship in Austrian High Schools. Subsequently, Fulbright provided her a scholarship at the Juniata College in Pennsylvania, where she could study and teach for a year. Currently, she is a PHD student at the University of Innsbruck. Her research interests include Literature and Film studies with the focus on interculturality and 
feminism. Besides, she teaches Culture Studies and German language courses at the University of Applied Sciences in Kufstein, Austria.

Publications: The Art of Reduction: Minimalism in Movies and Plays. (VDM Publishing House 2008); The Women in Hitchcock's Rebecca: Patriarchy's Penetrating Power. (Pennsylvania Communication Annual 2010). 